\title{
Towards understanding (religious) (in)tolerance in education
}

\begin{abstract}
Authors:
Ferdinand J. Potgieter ${ }^{1}$ Johannes L. van der Walt ${ }^{1}$ Charste C. Wolhuter ${ }^{1}$

\section{Affiliations:}

${ }^{1}$ Unit for Education and Human Rights in Diversity, North-West University, Potchefstroom Campus, South Africa
\end{abstract}

Correspondence to:

Ferdinand Potgieter

Email:

ferdinand.potgieter@nwu. ac.za

Postal address:

Private Bag X6001,

Potchefstroom 2520,

South Africa

Dates:

Received: 02 Apr. 2013

Accepted: 02 Aug. 2013

Published: 26 Feb. 2014

How to cite this article: Potgieter, F.J., Van der Walt, J.L. \& Wolhuter, C.C., 2014, 'Towards understanding (religious) (in)tolerance in education', HTS Teologiese Studies/Theological Studies 70(3), Art. \# 1977, 8 pages. http://dx.doi.org/10.4102/ hts.v70i3.1977

\section{Copyright:}

(C) 2014. The Authors.

Licensee: AOSIS

OpenJournals. This work

is licensed under the

Creative Commons

Attribution License.

Read online:
In recent years, schools and education authorities world wide have been paying increasing attention to issues surrounding diversity and religious (in)tolerance. The term 'tolerance' is, however, clouded by considerable confusion and vagueness. This article seeks to contribute to recent scholarly attempts at understanding (religious) tolerance and the term that denotes it. After a brief semantic analysis of the term 'tolerance', arguments concerning the onticity of tolerance as phenomenon or entity are discussed. By examining its onticity we explore and explain some of the essential features of tolerance. The article ends with a brief discussion of some of the implications of our examination that we foresee for (religion) education.

\section{Tolerance: Conceptual confusion and vagueness}

A review of the available literature of the past 9 years or so, reveals that the concept 'tolerance' is clouded by considerable confusion and vagueness (cf. Dawkins 2006; Dennett 2006; D'Souza 2007; Garrison 2007; Harris 2004; Haught 2008; Hitchens 2007; Leiter 2012; Mendus 2008; Powell 2013). ${ }^{1}$ Its diversity of meaning becomes obvious when it is used in conjunction with the adjectival qualifier 'religious' (Rangus 2001:1; Tobing 2013). To further complicate matters, the terms 'tolerance' and 'conflict' are often used in the same breath, seemingly in an attempt to denote propositions and counterpropositions in connection with religious attitudes. In some official international human rights documents, the words 'tolerance' and 'discrimination' are used interchangeably, ${ }^{2}$ whilst in others they are used to denote different phenomena (Rangus 2001:2).

In recent years, schools and education authorities world wide have been paying an increasing amount of attention to issues surrounding diversity and religious (in)tolerance (cf. Collins 2009; Goodin 2006; Ignatieff 2004; Jarvis 2009; Pape 2005; Qualifications and Curriculum Authority 2004, 2010; Roux 2000, 2006; Sardoc 2010). The need for tolerance has not only increased because of an epidemic of hate crimes committed, ${ }^{3}$ but also because of daily social interactions that require treating one another with respect and dignity. Religious intolerance is most frequently reflected in educational contexts such as classrooms, hallways and playgrounds, and manifests itself in the form of 'insults, angry outbursts, social cliques, put-downs and dismissals of others' viewpoints during class discussions' (cf. Gateways to Better Education 2005:1, 2; Schweitzer 2007:89). ${ }^{4}$

\section{On a methodological note}

We endeavour to add, on the basis of a semantic and etymological analysis, to recent scholarly attempts at understanding (religious) tolerance and the term that denotes it. Where appropriate, we also allude to relevant sociological notions. ${ }^{5}$ We firstly conduct a brief semantic analysis of the

1.We refer to tolerance (in italics) when we speak of it as onticity (as a phenomenon, entity or particular reality that may be viewed as a way of being), and to 'tolerance' (single quotation marks) as the concept or term that refers to that onticity. When 'tolerance' is used in normal print and not in inverted commas, it refers to either tolerance as onticity or to both.

2.To say that they can be used interchangeably seems counter-intuitive, unless 'discrimination' refers to singling out a particular person or group for special favour; to recognise or understand the difference between, to constitute or mark a difference, or to be discerning - in other words, to treat in a positive manner (cf. Sinclair 1999:410).

3.The current strife in Syria, the recent 'Arabic Spring' uprisings and the conflict between the Muslim north and the Christian south of Nigeria count as examples. Peck (2006:173) correctly points out that differences can exist between atheists and theistic believers as well as within religious groups: 'We see dogmatism, and proceeding from dogmatism, we see wars and inquisitions and persecutions. We see hypocrisy: people professing the brotherhood of man killing their fellows in the name of faith, lining their pockets at the expense of others, and practicing all manner of brutality' (Peck 2006:184). In Wright's (2009:421) view, 'the bulk of westerners and the bulk of Muslims are in a deeply non-zero-sum relationship, [and] by and large aren't very good at extending moral imagination to one another'. Alford (2009:57) concurs with him in saying that religious fundamentalism seems to be the cause of many of the world's ills, the reason for this being that people tend to operate from a narrower frame of reference (worldview) than what they are capable of, thereby failing to transcend the influence of their particular religion, culture, particular set of parents and childhood experience up their understanding (Peck 2006:180). Alford (2009-57) sees 'religious fundamentalism as the cause of so many of the world's ills upon their understanding (Peck 2006:180). Alford (2009:57) sees religious fundamentalism as the cause of so many of the world's ills - suicide bombers ..., intolerance .... The following statements seem to attest to this possibility: the name of the Islamic organisation which was suspected to be responsible for the 2010 Old Eve's bomb explosions in Nigeria (in which 23 people were killed) is Boko Haram, which literally means 'Western education is prohibited' (Okonta 2011:12); in 2012 a murder took place in a rural South African town, the victim was murdered just because he had a beard which is associated with Muslim men (Cilliers 2012).

4.Although education will not be frequently mentioned in the following semantic analysis, it should be kept in mind that the investigation was sparked off by incidences of intolerance in education, particularly schooling. The investigation was done for the purposes of providing theoretical substantiation for drafting a questionnaire on religious tolerance amongst teachers and their pupils (students). The pedagogical context should therefore never be lost sight of in the rest of the article.

5.We do not attempt to offer any psychological analysis of religious tolerance, although such an analysis may yet prove to be valuable for understanding, for example, the attitudes of individuals and groups. 
term 'tolerance'. This is followed by arguments concerning the onticity of tolerance as phenomenon or entity, and with an examination of its onticity through which we penetrate to the essential features of tolerance. ${ }^{6}$ Since the issues that have emerged from our study appear to have some implications for (religion) education; we therefore conclude the article with a brief discussion of some of the major implications.

\section{Conceptual-theoretical discussion Distinctive human attributes, actions and behaviour}

Numerous attempts at defining tolerance can be found in the literature. Little, as quoted by Tobing (2013:n.p.), defines it for example as 'a response to a set of beliefs that are originally thought to be objectionable, with disapproval but without using force or coercion [to change them]'. According to him, tolerance not only does not imply coercion of or force against an opponent, but rather respect of the other's viewpoint. Little (in Tobing 2013:n.p.) seems to claim that there exists some kind of relationship between repression of aggressive impulses and tolerance when he argues: 'It is natural for us to punish people we do not agree with. To repress that impulse is tolerant.' Little's (in Tobing 2013:n.p.) claim corresponds with Zagorin's (2003) explanation that tolerance represents:

the practice of deliberately allowing or permitting a thing of which one disapproves. One can meaningfully speak of tolerating, i.e. of allowing or permitting, only if one is in a position to disallow. (pp. 5-6)

These and most other definitions conceptually denote certain distinctive human attributes, such as individual(-ised) attitude, capacity, action, form of behaviour or response. Most definitions also seem to cover a considerable spectrum of descriptive and illustrative values (Enslin, Pendlebury \& Tjiattas 2001; Gateways to Better Education 2005; Rangus 2001; Schweitzer 2007; Tobing 2013; Van der Walt, Potgieter \& Wolhuter 2010; Visanmiu 2012). We return to this problem in the paragraph entitled 'Tolerance in terms of a spectrum of behaviour' below.

\section{Modern liberal views of tolerance}

The liberal ideal of tolerance which looks at a rational consensus (cf. Habermas 1984, 1992) 'on the best way of life was born in societies divided on claims of a single way of life' (cf. Kelly, 1988:442). It cannot show us in modern times how to live together in societies that harbour many ways of life. Our task nowadays 'is to consider what becomes of this patrimony in societies which are much more deeply diverse than those in which liberal [tolerance] was conceived' (Gray 2009:22). Because of industrialisation, globalisation and digitalisation, the autonomy of the individual has steadily gained preference vis-à-vis that of the group. Human rights are increasingly being construed as individual human rights (cf. Angus 2004; Apple 1999, 2004; Bates 1996; Boyd \& Lugg 1998; Budhwar \& Debrah 2004; Codd 2005; Gewirtz \& Ball

6.Although this study does not purport to be a phenomenological investigation, we nevertheless followed Husserl's appeal that the investigator should 'go back to the things themselves' (Du Plooy, Griessel \& Oberholzer 1983:218).
2000; Gewirtz 2002; Hall 2005; Kelchtermans, 2009, 2012; Meyer 2002; Morley \& Rassool 2000; Moses 2004; Schneider 2003; Simkins 2000; Thrupp \& Willmott 2003; Tikly 2003; Torres 2002; Webster \& Mosoetsa 2002; Wright 2001; Zipin \& Brennan 2003). How we can and should relate to this development seems to be a pivotal question with regard to the being and meaning of tolerance. Liberal freedom, for example, does not seem to tolerate a person who has derived his or her identity from (and associates it with) a larger group (i.e. heteronomy). Liberal freedom seeks to liberate such people. This is why Gray (2009:21) claims that we should see it as our task to refashion liberal tolerance so that it can guide the pursuit of a modus vivendi in a more plural world. In the classical sense, liberal tolerance has contributed immeasurably to human well-being, but, for the reasons posited above, it cannot be our guide in late modern circumstances (Gray 2009:21).

Tolerance is not only the centrepiece but also the paradox of liberalism: Liberalism propounds tolerance of opposing viewpoints and allows them to have their say, leaving it to the democracy of ideas to decide which of them shall prevail (Grayling 2009:8). Paradoxically, liberalism also allows intolerance as a view (Walzer 1997:80, 81) but in essence does not tolerate intolerance. Instead, it opts to employ the power of argument and honest reasoning. As Grayling (2009:8) rightly avers, one can be confident that in most cases the reasoning of an informed mind will come out in favour of what can be tolerated (cf. Dworetzky 1981:53, 54). ${ }^{7}$

\section{Semantic exploration of the term 'tolerance'}

As authors, we have a good command of three languages, namely English, Dutch (as well as South African Afrikaans which is akin to Dutch) and German. In Dutch and German, the term 'tolerance' appears in two forms. The Germanic term for 'tolerance' in Dutch and Afrikaans is 'verdraagsaamheid' and in German it is 'Erträglichkeit'. All four languages nowadays seem to prefer the Latinate form: English - 'tolerance'; Dutch - 'tolerantie'; Afrikaans - 'toleransie' and German - 'Toleranz'.

According to Sinclair's Collins Concise Dictionary (1999:410), the word 'tolerance' is derived from the Latin 'tolerāre' (Eng. 'to sustain'; 'to endure' [Soames \& Stevenson 2008:455]). A semantic analysis of the Dutch 'verdraagsaamheid' and the English 'forbearance' reveals interesting parallels. In Dutch, the signifier is 'dragen', which means 'to bear'. The addition of the prefix 'ver-' creates the verb 'verdragen' (Eng.

7.Intolerance is a psychologically interesting phenomenon because it is symptomatic of insecurity and fear. Zealots, who would, if they could, persecute you into conforming to their way of thinking, might claim to be trying to save your soul despite yourself; but they are really doing it because they feel threatened. Fear begets intolerance, and intolerance begets fear' (Grayling 2000:n.p.). The cycle seems indeed to be a vicious one. In light of the above, it is not difficult to understand why some people who belong to extremely orthodox, fundamentalist faith communities may experience the notion of tolerance as painful. It essentially asks of them to betray their own confessional convictions and life-view-related norms, values and attitudes. Tolerance nevertheless remains an important attitude for orthodox believers as well. On the one hand the global society in genera for orthodox believers as well. On the one hand, the global society in general tends to support a liberal interpretation of behaviour: everyone has the right to come to his or her own conclusions; the individual is increasingly becoming the standard yardstick of all things (even though many religions contest the proposa Driestar Educatie Gouda, Netherlands] pers. Comm., 08 December 2011). On the other hand tolerance increasingly becomes a valid question for every religion and religious denomination, because no one can ever claim monopoly of and over the truth. 
'to forbear'). In Dutch, the addition of the suffix '-saam' not only changes the word into the adjective 'verdraagsaam', but also intensifies the meaning (Eng. 'forbearing') in the sense that it now refers to something beyond itself, namely to an attitude, an action or some form of behaviour. The adjective refers to a state or condition, the state or condition of being tolerant, of exhibiting some kind of exemplary, internalised behaviour or attitude characterised by a propensity $(\mathrm{N}$. Boersma, [Driestar Educatief, Gouda, Netherlands] pers. Comm., 08 December 2011) to forbear another person or his or her attitude and behaviour. The further addition of the Dutch suffix '-heid' changes 'verdraagsaam' into the noun 'verdraagsaamheid' (Eng. 'forbearance', tolerance). All these changes can be detected in English as well: 'bear' - 'forbear' - 'forbearing' - 'forbearance'. What is interesting, is that the English word 'bear' is akin to the Dutch verb stem 'baren' (to bear, to give birth; cf. Eng. 'born', 'borne' and 'birth' - all of Germanic origin).

As far as the English word 'tolerance' is concerned, we can see the same process of intensification unfolding, except that there seems to be no Latinate form for 'to bear' in the sense of 'to carry'. The verb takes the Latinate form 'tolerate'; the adjective is 'tolerant' and the noun 'tolerance' (from the 16th century onwards, preferable to the older form of 'toleration').

In all these languages, the noun 'verdraagsaamheid' (and its synonyms in other languages, such as 'forbearance', 'tolerance') seems to denote an entity (state, condition or propensity) with a certain observable (albeit abstract) status. This entity or 'being' (ontic) status can only be observed as a quality, attitude, action or behaviour of a person with respect to something else, such as a certain state of affairs, or another person's or group's actions, behaviours and attitudes. In this sense, it has the same ontic status (onticity) as (abstract) entities such as hate, love, respect, education, endurance, kindness, sympathy - all of which can only be observed via attitudes, actions or behaviour. Put differently, 'tolerance' possesses the ontic status of a mental construct that comes into existence through (theoretical) analysis, enquiry, discourse, critical thinking, reflection and self-reflection, the creation of rational coherence, theory-construction, hermeneutic interpretation, conceptualisation, the use of logical space of reasons, propositional relationships, sensory qualia and mental imagery (Van der Walt \& Fowler 2006:33, 34).

Based on the assumed ontic status of tolerance we now proceed to reflect on a possible ontology of tolerance. ${ }^{8}$

\section{An ontology of tolerance Thinking ontologically about tolerance}

Ontology is the study of being, or of that which is (Bochenski 1972:84) (with 'being' the best English translation for the German word 'sein'; the French word 'etre'; the Dutch word 'zijn' or the Afrikaans words 'syn' or 'werklikheid'). 'Onticity' would thus mean existing in being. What we attempt to do in this section is to investigate the ontic or 'being' status 8.See footnote 1 . of 'tolerance': does it exist in being, a-priori to human invention, or is it a human artefact or invention? This process involves an epistemology centring on hermeneutics and phenomenology, and not on the development of an ontology (which would constitute a scientific contradiction).

A (religion) educationist should be aware of the 'being' of all things (religiously) educational, in other words the ontology that he or she entertains, including the phenomenon or onticity of (in)tolerance. Ontology as a discipline focuses on questions regarding the relationships between the individual and the universal, unity and diversity, uniqueness and coherence, the unchangeable and the changeable, that which is determined and that which may be regarded as contingent, the knowable and the unknowable, the preconditions for (in this case, tolerance) and that which is conditioned by them as well as the relationship between wholes and their parts (Van der Walt \& Potgieter 2012:222). (Religion) educationists therefore should have an understanding of where entities in reality, including (religious) (in)tolerance originated, or how they believe it to have originated, and what its 'being' means or constitutes. Before we can give a name to the phenomenon of tolerance or (in)tolerance respectively, we must first understand what onticity is. This can be done by hermeneutic-phenomenologically searching for its essential features and by constantly corroborating the upshot with the available scholarly literature on the subject.

\section{The essential features of tolerance Tolerance involves decision-making based on values}

Tolerance implies the degree of deviation from a set standard, norm, principle and/or value that a person is willing to allow. What a person tolerates will depend on the rigidity or rigorousness of that norm. According to Lusenga (2010:19), these standards, norms or values are the principles by which a person lives or the conception of the desirable that guides a person to make choices and decisions in given situations. These standards, norms or values, can be both implicit and explicit assertions of what is desirable, important, useful or worthy for a person, predispose the allowable degree of variation with which that person may be prepared to tolerate opinions, practices, races, religions, nationalities, et cetera, that may differ from his or her own. The allowable degree of latitude depends on how a principle or value has been formulated, and this implies conscious decision-making. The decision-making, as Morton (1998:167) explains, occurs within the dynamics created by the values of other people, own and others' preferences, likes or dislikes and leads to different forms of behaviour for different people (Morton 1998:168).

\section{Tolerance involves ethical behaviour}

As mentioned:

if liberalism has a future, it is in giving up the search for a rational consensus on the best way of life. Nearly all societies today contain several ways of life, with many people belonging to more than one. (Gray 2009:22) 
Rational inquiry in ethics - including the ethics of tolerance - therefore does not yield consensus on the best life; it shows that the good life comes in many varieties. What is new in the modern world, according to Gray (2009:22), is not acceptance of diversity (i.e. difference) in styles of life but rather hostility to hierarchies. We need to understand that humans nowadays prefer to live differently and yet should strive towards living peacefully together (Gray 2009:24, 25). J.S. Mill's view (quoted by Grayling 2002:7) remains relevant even today: 'Mankind are greater gainers by suffering each other to live as seems good to themselves, than by compelling each to live as seems good to the rest.'

Mill's view carries a number of significant implications for our time. It defines a tolerant person as one who respects the differences amongst human beings or within a society. A tolerant person also holds that the human community benefits by permitting a variety of lifestyles to flourish because they represent experiments from which much ought to be learned about how to deal with the human condition. He or she furthermore upholds the premise that no one has the right to tell another how to be or how to act, provided that such being and acting does no harm to others (Grayling 2002:7). ${ }^{9}$ To permit, allow, comply or forbear is a form of tolerance that is easy to defend from a purely pragmatic point of view: We permit, allow, comply and forbear because we have a right to live our own lives and therefore do not want to radicalise or subject everything to some kind of inquisition. It simply makes practical sense to do so.

'Tolerance' is a social concept that not only refers to the mental construct tolerance but also requires serious philosophical (theoretical and conceptual) reflection. As De Botton (2012) avers:

We will never discover cast-iron rules of good conduct which will answer every question that might arise about how human beings can live peacefully and well together. However, a lack of absolute agreement on the good life should not in itself be enough to disqualify us from investigating and promoting the theoretical notion of such a life. (p. 83)

It therefore follows that in education all stakeholders and role players should, at all times, have an understanding of tolerance and intolerance as mental constructs.

\section{Tolerance involves reasonable argument}

Faith and religious thoughts and actions are based on deliberate reflection and reasoning. A religiously tolerant person, for instance, will allow others with opposing viewpoints to have their say and will then leave the upshot to what Grayling (2007:8) refers to as the democracy of ideas, that is, the power of argument to decide which ideas shall

9. Although this modern liberal view of tolerance might explain the need and fact of tolerance in the secular environment that is currently taking root all over the world, tolerance in the secular environment that is currently taking root allover the world it might not be satisfactory to (religion) educationists preferring to educate and to look at tolerance from a particularist, confessional perspective. Permitting, allowing, complying and forbearing may be a preferable middle ground to some followers of many orthodox religions: they may not necessarily be denouncing something, but they may be prepared to avert their eyes temporarily. prevail. The only coercion in these conditions, Grayling (2002:9) correctly argues, should be that of argument; the only obligation should be honest reasoning. ${ }^{10}$ In saying this, Grayling harks back to the opinion of J.S. Mill who said that one should reason with a person holding a view that is incorrect according to your opinion (Mill in Morton 1998:170). On the one hand, Mill (in Morton 1998:171) defends the right of individuals to express their beliefs freely, even when those beliefs contradict widely-held political, religious or moral beliefs. On the other hand, he stresses the benefits of free reasonable discussion with such persons.

Morton (1998:172) derives two principles from Mill's view: Free and open discussion is a social good, and free and questioning discussion often leads to discovery of the truth. In the present case, free and questioning discussion will lead to discovery of what is acceptable regarding religious tolerance. Discussion will reveal the reasons for (in casu, religiously intolerant) beliefs and actions; discovery of those reasons will affect an individual's choices. In sum, says Morton (1988:173), individuals need to think hard about what one might call a person's map of certainty amongst his or her beliefs. The best way to do this is by being intelligently sceptical. Peck (2006:4) agrees: It is only when we encounter problems (in this case, with an intolerant life and worldview) that we grow mentally and spiritually (Peck 2006:174). To develop a realistic religious perspective and/or worldview, that is, one that conforms to the reality of the cosmos and our role in it (including what actions are expected of us in it), we must constantly revise and extend our understanding to include new knowledge in the larger world.

\section{Tolerance implies difference}

One of the reasons why some people may choose to be tolerant of others who exhibit intolerant behaviour could be traced back to the uniquely human characteristic of individuation and separation (as advocated by Developmental Psychology) (N. Boersma [Driestar Educatief, Gouda, Netherlands] pers. Comm., 08 December 2011); in other words, to the notion of difference - that which makes each person unique (Visker 1996, 2004). If we asked the mental constructs tolerance and intolerance: 'Why are you here?' and demanded from them to give account of themselves, the answers that surface all seem to point to constructs outside of these two constructs themselves. In the case of tolerance, the answers point to human qualities such as kindness, patience, courtesy, humility, self-control, courage, resilience, respect, et cetera; and, in the case of intolerance, to human qualities and behaviours such as stereotyping, discrimination, avoidance

10.La Folette (2007:7) offers two sets of practical guidelines for conducting such a reasonable discussion. Firstly, we have to ask ourselves whether an argument or a view is plausible, defensible, based on full information, careful calculation, astute perception, and if it has successfully survived the criticism of others in the marketplace of ideas (i.e. the power of argument). The second set entails the execution of six steps to decide whether a view, argument or action can be morally justified: (1) we should strive to make an informed decision based on morally justified. (1) we should strive to make an informed decision based on the best evidence and then act accordingly, even though the best evidence wil never guarantee certainty. (2) To make such an informed decision, the discussant should understand the relevant issues, (3) take a longer-term perspective, (4) se aside irrational biases, (5) and inculcate a willingness to subject their tentative conclusions to the criticisms of others. (6) And finally, the discussants should acknowledge their uncertainty, admit their fallibility, and be prepared to consider new ideas, especially when they are supported by strong arguments. 
and religious conflict (Wolhuter, Van der Walt \& Potgieter 2014:10-17).

If we asked difference to explain why it is here and to give account of itself one notices that it is not able to give an account of itself in terms of something outside of itself in the same way that (in)tolerance was able to do. This is, according to Visker (2005), because difference seems to reside and rest in itself; it can only point to itself, suggesting that it may be its own reason-for-being. Visker $(2004: 13,25,46)$ says that this is because difference is only accessible to the thing or person who actually carries the difference. With reference to Spinoza, Visker (1997:158) explains that everything - insofar as it is in itself - endeavours to persist in its being, adding that 'a thing cannot have anything within itself whereby it can be destroyed.' The reason for difference therefore rests within difference itself, suggesting to us that it may be the ontic fountainhead from which all intolerant attitudes and behaviour may spring. Put differently, if difference did not exist (did not have ontic status) there would have been no cause to discriminate against or be intolerant of others with different attributes.

It may be argued that this line of reasoning by Visker presupposes an idealistic, Platonian, abstract human being who is somehow disengaged from all culture (cf. Visker 1997:159), whereas the daily conatus essendi reality of all human beings - albeit somewhat simplistic - seems to suggest that everybody is always attached to, rooted in, absorbed by and fully immanentised into a particular (cultural) context or series of related contexts (cf. Visker 1997:159). So, although the reason for difference may very well rest within difference itself, the context-bound, daily conatus essendi reality of us human beings allows for difference to be comprehended in terms of observable qualities outside of itself.

This helps to explain why all observable instances and examples of intolerance that are based on perceived differences are merely attempts at depriving the Other ${ }^{11}$ of their alterity (Visker 1997:160), to reduce them to their 'form' - the colour of their skin, the physiognomy of their face, et cetera. The alterity of the Other is thus reduced to particular characteristics which make them different from us and, in this way, the Other is robbed of their mystery or their enigma - a mystery which consists precisely of the fact that the Other's alterity is not the consequence or the sum of their other 'qualities', but precedes them; is independent of them. To reduce the Other to their form, to their role, to their context, to contextualise them within their culture is tantamount to murdering them, depriving them of their unique dignity, reducing them to exemplars of some or other sort, taking from them that which makes them each to be a singular person - in short, misrecognising their individual personhood. It denies the other the privilege to become and to be - first and foremost - a person (Visker 1997:161).

This, then, also helps to explain why tolerance seems to come into play when we are confronted with the outwardly

11.Visker refers to the alterity of the other person as "Other' (Fr autrui) with a capital ' $\mathrm{O}$ ', in much the same way as has been done earlier by Emmanuel Levinas. observable instances of perceived difference - in terms of these above-mentioned contexts where it becomes possible for human beings to perceive, for example, culture, religion, habits, customs, clothing, cuisine and manners. Tolerance can, therefore, be understood as the outgrowth of character qualities such as kindness, patience, courtesy, humility, selfcontrol, and courage - each of which is underpinned by a particular hierarchy of values. Intolerance (or, more correctly, especially intolerance) is also usually expressed through these personal qualities (Gateways to Better Education 2005:1, 2).

\section{Tolerance implies a spectrum of behaviour}

According to Vermeer and Van der Ven (2004) and Cush and Francis (2006), (religious) behaviour could be plotted on a spectrum. At the one end of the spectrum tolerance may be understood to reflect a permissive, laissez-faire and completely inclusivist attitude toward those whose opinions, practices, race, religion, nationality, et cetera, may differ from one's own.

Towards the middle of the spectrum, tolerance is usually understood to represent an attitude that reflects freedom from bigotry. Tolerance is an individual ability to treat someone or something with indulgence or forbearance, to bear, to put up with. In this sense, to tolerate means to allow the existence or occurrence - of something that one dislikes or disagrees with - to endure with forbearance. A person may condone what he or she cannot concede, but which he or she nevertheless forbears. Tolerance is also understood to be an (individual) act of showing interest in and concern for those ideas, opinions, practices, et cetera, that may be foreign to one's own; it represents a liberal, undogmatic viewpoint with regard to such opinions, practices, race, religion, nationality, et cetera. Towards the middle of the spectrum, tolerance is usually described as a fair, objective attitude toward such opinions, practices, race, religion, nationality, and so forth. It is also understood as an individual's capacity to endure - a kind of sustained behaviour of resilient endurance. Human beings are naturally diverse (i.e. different) in many ways; tolerance therefore means, amongst others, accepting every reasonable way of being human (Visanmiu 2012:1, 2). Acceptance and tolerance are however, not the same thing, because one can tolerate something without actually accepting it. What underlies tolerance seems to be:

the recognition that there is plenty of room in the world for alternatives to [co-exist], and if one is offended by what others do, it is because one has let it get under one's skin. (Grayling 2009:9)

At the opposite end of the spectrum, we find extremely intolerant behaviour due to extreme dogmatism and orthodoxy flowing from socially unacceptable stances such as religious extremism and exclusivism, fundamentalism and even fanaticism.

All of the following stances can, for example, be plotted on this spectrum or continuum: from inclusivism to exclusivism, from religio and dialogic pluralism to religio-centrism, from 
discrimination, fundamentalism, stereotyping, defensiveness to wholehearted acceptance of religious and other differences in other people (also see Gateways to Better Education 2005:2; Wolhuter, Van der Walt \& Potgieter 2014:1, 2, 10-17).

The foregoing analysis of 'tolerance' and tolerance has important pedagogical implications, particularly for religious education, as well as for religion education. ${ }^{12}$ The following implications flow from the above discussion.

\section{(Religion) Pedagogical implications}

\section{Religion educationists should possess a profound understanding of (religious) tolerance}

The child comes into the world from the maternal lap of human society and finds his or her abode in a world of fellow human beings who differ on many grounds, including in terms of life and a worldview. Inherent in the condition of childhood is the idea of yet-to-be (Du Plooy et al. 1983:46); in order for children to learn the virtues of tolerance towards those who may differ from them, they are also dependent on education of, for and about tolerance. This implies that their teachers and caregivers must command a profound understanding of the essential features of tolerance as a mental construct and how contextual contingencies, coupled with human attitudes, actions and behaviour impact on its realisation or, alternatively, on its negation (privation) such as intolerance.

\section{Religion educationists should inculcate (religious) tolerance from an early age}

Tolerance is a uniquely human phenomenon, construct and concept. It is therefore of import that the inculcation of (religious) tolerance in terms of culture, religion, habits, customs, clothing, cuisine, manners et cetera should start at an early age. Even very young children should be taught that tolerance means respecting, accepting, appreciating and, sometimes, even celebrating and embracing the rich variety of human differences.

\section{Religion educationists should focus on observable behaviours and attitudes to redress the problem of (religious) intolerance}

Tolerance is not a final product; it is always a work-inprogress. It is never a destination, but always a journey. One is not tolerant, per se; one becomes (progressively more) tolerant over a period of time. This journey is (and should be) plotted along particular observable behavioural and attitudinal coordinates (which can then, retrospectively, be used to assess, evaluate and rectify any problems that may occur along this journey). This implies that educationists should focus on inculcating and encouraging behaviour such as love, respect, compassion, endurance, kindness, sympathy, patience, forgiveness, mercy, et cetera in order to pre-empt and redress the problem of (religious) intolerance.

12.It might also have implications for an empirical survey about the state of religious tolerance amongst religion education teachers and their learners. Each of the implications discussed below could be rephrased and used as an item in questionnaire.
Religion educationists should be informed about the liberal view of tolerance, especially as it has been modified to suit modern society

It seems that the liberal ideal of tolerance which looks at rational consensus on the best way of life, remains worthy of our consideration. The reason for this being that liberalism propounds tolerance of opposing viewpoints and allows them to have their say, leaving it to the democracy of ideas and the power of argument to decide which of them shall prevail. This implies that educationists should be well informed about the essence, limits, place and role of the modus vivendi approach to tolerance.

\section{Religion educationists should create safe dialogic-diagogic spaces for inculcating tolerant behaviour}

Educationists should consider constructing dialogic spaces (see Rule 2004) where teacher-educators and learners may be allowed the freedom to explore the potentially unifying power of honest conversation (on a dialectical niveau) with regard to religious differences. These dialogic spaces should be constructed as safe diagogic spaces where all participants may securely explore (and learn to assign meaning to) the full spectrum and continuum of tolerance-related issues, attitudes, actions and behaviours.

\section{Religion educationists should strategise their interventions with intolerant learners on the basis of the five essential features of intolerance discerned above}

Focus on tolerance as dependent on conscious decisionmaking

In order to set out on the journey towards becoming a tolerant person, it is vital that teacher-educators, caregivers and learners alike should understand that tolerance, in the final analysis, always involves conscious, deliberate decisionmaking.

\section{Focus on tolerance as dependent on reasonable argument}

As part of the socialisation process that forms the core of education, logical argument and honest reasoning should lead teacher-educators, caregivers and learners to understand all the relevant issues concerning religious and other forms of (in)tolerance. Through the power of reasonable argument they should strive always to take a longer-term perspective and to set aside irrational biases. Teacher-educators should seek to inculcate in their learners a willingness to subject their tentative conclusions to the criticisms of others whilst refraining from exhibiting intolerant behaviour. All discussants should acknowledge their uncertainty, admit their fallibility and be prepared to consider new ideas, especially when these are supported by strong arguments.

\section{Focus on tolerance as dependent on personal ethical orientation}

Humans will always have reason to live differently. A modus vivendi seems to be one of the more ideal ethical orientations 
through which we can work towards a more tolerant society. Learners should be taught and educated that permitting, allowing, complying and forbearing all constitute acceptable forms of tolerance because everyone has a right to live their own lives and because it makes practical sense to do so.

\section{Focus on tolerance as dependent on understanding difference}

As argued, the essence of tolerance or intolerance seems to derive its intelligibility from the onticity difference. Tolerance only seems to come into play when we are confronted with differences of whatever nature. If teacher-educators and caregivers can lead learners to understand this, it should make it easier for them to teach their learners what tolerance means in the context of the rich diversity of our world's cultures.

\section{Focus on tolerance as exhibiting a spectrum or continuum of behaviour}

Teacher-educators and caregivers should teach their learners that tolerant behaviour may be exhibited that ranges depending on time, circumstance and context - from a permissive, laissez-faire (inclusivist) attitude, on the one end of an imaginary spectrum, to an attitude that reflects (in the middle of the continuum) freedom from bigotry or an individual ability to treat someone or something with indulgence or forbearance, a fair, objective attitude or a kind of sustained behaviour of resilient endurance, to an exclusivist, discriminatory and stereotypical stance at the other end of the spectrum. This spectrum or continuum differs from person to person, and from community to community and may include various stances. In order to teach learners that tolerance and intolerance are not only or even invariably forms of acceptance and rejection respectively, educationists should be well-informed about the many variations along the continuum.

\section{Conclusion}

We hope to have contributed somewhat to recent scholarly attempts at understanding the concept 'tolerance', respectively 'intolerance'. Our semantic study showed that the term 'tolerance' has a certain width of meaning of which (religion) educationists should take cognisance. Our ontological study contributed a series of essential features of tolerance of which (religion) educators and educationists also should be aware. In view of our findings, educators should problematise intolerant views and help the younger generation to work through them, think about them and thus arrive at a more balanced life and worldview, including a view of others and the differences they display. Educators who understand all these niceties will be able to guide the children in their care towards better peaceful coexistence as future adults.

\section{Acknowledgements Competing interests}

The authors declare that they have no financial or personal relationship(s) that may have inappropriately influenced them in writing this article.

\section{Authors' contributions}

C.C.W. (North-West University) was responsible for some of the literature scooping and for drafting the paragraphs on modern liberal views of tolerance and the semantic exploration of the term 'tolerance'. J.L.v.d.W. (North-West University) and F.J.P. (North-West University) were coresponsible for everything else. F.J.P. wrote the manuscript, whilst J.Lv.d.W. edited the final draft.

\section{References}

Alford, H., 2009, How to live: A search for wisdom from old people, Twelve Books, New York, NY.

Angus, L., 2004, 'Globalisation and educational change: bringing about the reshaping and re-norming of practice', Journal of Education Policy 19(1), 23-41. http:// dx.doi.org/10.1080/0268093042000182618

Apple, M.W., 1999, 'Freire, neo-liberalism and education', Discourse: Studies in the Cultural Politics of Education 20(1), 5-21.

Apple, M.W., 2004, 'Creating difference: Neo-liberalism, neo-conservatism and the politics of educational reform', Educational Policy 18(1), 12-44. http://dx.doi. org/10.1177/0895904803260022

Bates, R., 1996, 'The educational costs of managerialism', paper presented at the Joint conference of the Educational Research Association, Singapore and the Australian Association for research in Education, Singapore Polytechnic, Singapore, 25-29 November.

Bochenski, J.M., 1972, Philosophy: An introduction, Harper and Row, New York, NY.

Boyd, W. \& Lugg, C., 1998, 'Markets, choices and educational change', in A. Hargreaves, A. Liebermann, M. Fullan \& D. Hopkins (eds.), The international handbook of educational change, pp. 349-375, Kluwer Academic, Dordrecht.

Budhwar, P. \& Debrah, Y.A., 2004, Human resource management in developing countries, Routledge, London.

Cilliers, C., 2012, 'Moord op Moslem: Twee gearresteer', Beeld, besigtig 12 Augustus 2012, by http://www.Beeld/com.Suid-Afrika/nuus/moord-op-Moslem-tweegearresteer-20120812

Codd, J., 2005, 'Teachers as "managed professionals" in the global education industry: The New Zealand experience', Educational review 57(2), 193-206. http://dx.doi. org/10.1080/0013191042000308369

Collins, J.R., 2009, 'Redeeming the enlightenment: New histories of religious toleration', The Journal of Modern History 81(3), 607-636. http://dx.doi. org/10.1086/599275

Cush, D., 1994, 'A suggested typology of positions on religious diversity', Journal of Beliefs and Values 15(2), 18-21. http://dx.doi.org/10.1086/599275

Cush, D. \& Francis, D., 2006, “"Positive pluralism” to awareness, mystery and value: A case study in religious education curriculum development', British Journal of Religious Education 24(1), 52-67. http://dx.doi.org/10.1086/599275

Dawkins, R., 2006, The God delusion, Houghton Mifflin, Boston, MA.

De Botton, A., 2012, Religion for atheists, Hamish Hamilton, London.

Dennett, D.C., 2006, Breaking the spell: Religion as a natural phenomenon, Viking, New York, NY.

D'Souza, D., 2007, What's so great about Christianity?, Regnery, Washington, DC.

Du Plooy, J.L., Griessel, G.J. \& Oberholzer, M.O., 1983, Fundamental pedagogics for advanced students, HAUM, Pretoria.

Dworetsky, J.P., 1981, Introduction to child development, West Publishing Company, St. Paul, MN.

Enslin, P., Pendlebury, S. \& Tjiattas, M., 2001, 'Deliberative democracy, diversity and the challenges of citizenship education', Journal of Philosophy of Education 35(1), 115-130. http://dx.doi.org/10.1111/1467-9752.00213

Garrison, B., 2007, The new atheist crusaders and their unholy grail: The misguided quest to destroy your faith, Thomas Nelson, Nashville, TN.

Gateways To Better Education, 2005, Promoting tolerance: How to make a change, viewed 09 January 2013, from http://www.gtbe.org/news/images/promoting tolerance.pdf

Gewirtz, S., 2002, The managerial school: Post-welfarism and social justice in education, Routledge, London.

Gewirtz, S. \& Ball, S., 2000, 'From "welfarism" to "new managerialism": Shifting discourses on school headship in the education market place', Discourse: Studies in the cultural Politics of Education 21(3), 253-268.

Goodin, R.E., 2006, What's wrong with terrorism?, Polity Press, Cambridge.

Gray, J., 2009, Gray's anatomy, Allen Lane, London.

Grayling, A.C., 2000, 'The last word on tolerance', The Guardian, 01 July, viewed 12 February 2011, from http://www.theguardian.com/books/2000/jul/01/books. guardianreview7

Grayling, A.C., 2002, The meaning of things, Phoenix, London. 
Grayling, A.C., 2007, The meaning of philosophy: Applying philosophy to life, Phoenix, London.

Grayling, A.C., 2009, Thinking of answers, Bloomsbury, London.

Habermas, J., 1984, The theory of communicative action, vol. 1: Reason and the rationalization of society, transl. T. McCarthy, Beacon Press, Boston, MA.

Habermas, J., 1992, 'Themes in post-metaphysical thinking', transl. W.A. Hohengarten, in Post-metaphysical thinking: Philosophical essays, pp. 28-57, MIT Press, Cambridge, MA.

Hall, K.D., 2005, 'Science, globalisation and educational governance: The political rationalities of the new managerialism', Indiana Journal of Global Legal Studies 12(1), 53-182. http://dx.doi.org/10.2979/GLS.2005.12.1.153

Harris, S., 2004, The end of faith: Religion, terror and the future of reason, Norton, New York, NY.

Haught, J.F., 2008, God and the new atheism: A critical response to Dawkins, Harris and Hitchens, Westminister John Knox Press, Louisville, TN.

Hitchens, C., 2007, God is not great: How religion poisons everything, Twelve Books, New York, NY.

Ignatieff, M., 2004, The lesser evil: Political ethics in an age of terror, Edinburgh University Press, Edinburgh. http://dx.doi.org/10.3366/edinburgh/9780748618729.001.0001

Jarvis, J., 2009, 'Teacher identity in a context of religious diversity', Alternation Special Edition 3(1), 157-176.

Kelchtermans, G., 2009, 'Who I am in how I teach is the message: self-understanding, vulnerability and reflection', Teachers and Teaching: Theory and Practice 15(2), 257-292. http://dx.doi.org/10.1080/13540600902875332

Kelchtermans, G., 2012, De leraar als (on)eigentidjse professional: Reflecties over de 'modern professionaliteit' van leerkrachten, Centrum voor Onderwijsbeleid -vernieuwing en leeraaropleiding, KatholiekeUniversiteit Leuven, Leuven.

Kelly, J.P., 1988, 'No one model American: A statement on multicultural education', in K. Ryan \& J.M. Cooper (eds.), Kaleidoscope: Readings in education, pp. 439-459, Houghton Mifflin, Boston, MA.

La Folette, H., 2007, Ethics in practice, Blackwell, Oxford.

Leiter, B., 2012, Why tolerate religion, Princeton University Press, Princeton, NJ.

Lusenga, R.M., 2010, 'School leaders' moral understanding and moral reasoning', mini dissertation, Department of Education Management, Law and Policy Studies, University of Pretoria.

Mendus, S., 2008, The Freilich lectures 2007: Religious toleration in an age of terrorism, Freilich Foundation, Australian National University, Canberra, viewed 09 April 2013, from http://eprints.whiterose.ac.uk/7789/

Meyer, H.D., 2002, 'The new managerialism in education management: Corporatization or organisational learning?', Journal of Educational Administration 40(6), 534or organisational learning?', Journal of Educational
551. http://dx.doi.org/10.1108/09578230210446027

Morley, L. \& Rassool, N., 2000, 'School effectiveness: New managerialism, quality and the Japanization of education', Journal of Educational Policy 15(3), 169-316. http://dx.doi.org/10.1080/026809300285881

Moses M.S., 2004, 'Social welfare, the neo-conservative turn and educational opportunity', Journal of Philosophy of education 38(2), 275-286. http://dx.doi. org/10.1111/j.0309-8249.2004.00382.x

Morton, A., 1998, Philosophy in practice, Blackwell Publishers, Malden, MA.

Okonta, I., 2011, 'Nigeria's restive north', The Citizen, 10 October, p. 12.

Pape, R., 2005, Dying to win: The strategic logic of suicide terrorism, Random House, New York, NY.

Peck, S., 2006, The road less travelled, Random House, London.

Powell, R., 2013, 'Religion, tolerance and intolerance: Views from across the disciplines', in S. Clarke, R. Powell \& J. Savulescu (eds.), Religion, intolerance and conflict: A scientific and conceptual investigation, pp. 2-36, Oxford University Press, Oxford. http://dx.doi.org/10.1093/acprof:0so/9780199640911.003.0001

Qualifications and Curriculum Authority (United Kingdom), 2004, Religious education: The non-statutory national framework, viewed 20 July 2013, from http://www. theredirectory.org.UK/public_docs/Non-statutory_national_Framework_/ RE_0410.pdf

Qualifications and Curriculum Authority (United Kingdom), 2010, Religious Education in English schools: Non-statutory guidance 2010, viewed 20 July 2013, from http://www.teachernet.gov.uk/publications

Rangus, E., 2001, 'Religious tolerance starts with a definition', in Emory Report, viewed 02 April 2001, from http://www.emory.edu/EMORY_REPORT/erarchive/2001/ April/erApril.2/4_2_01tolerance

Roux, C.D., 2000, 'Multireligious education - An option for South Africa in the New Education System', British Journal of Religious Education 22(3), 173-180. http:// dx.doi.org/10.1080/0141620000220305

Roux, C.D., 2006, 'Children's spirituality in social context: a South African example', International Journal of Children's Spirituality 11(1), 151-163. http://dx.doi. org/10.1080/13644360500504462
Rule, P., 2004, 'Dialogic spaces: Adult education projects and social engagement' International Journal of Lifelong Education 23(4), 319-334. http://dx.doi. International Journal of Lifelong
$\mathrm{org} / 10.1080 / 026037042000233476$

Sardoc, M., 2010, 'Toleration, respect and recognition: Some tensions', Educational Philosophy and Theory 42(1), 6-8. http://dx.doi.org/10.1111/j.14695812.2009.00546.x

Schneider G., 2003, Neo-liberalism and economic justice in South Africa: Revisiting the debate on economic apartheid', Review of Social Economy 61(1), 23-50. http://dx.doi.org/10.1080/0034676032000050257

Schweitzer, F., 2007, 'Religious individualization: New challenges to education for tolerance', British journal of Religious Education 29(1), 89-100. http://dx.doi. org/10.1080/01416200601037551

Simkins, T., 2000, 'Education reform and managerialism: comparing the experience of schools and colleges', Journal of Educational Policy 15(3), 317-332. http://dx.doi. org/10.1080/02680930050030455

Sinclair, J.M., 1999, s.v. 'tolerance', in J.M. Sinclair (ed.), Collins concise dictionary, Harper Collins, Glasgow, p. 410.

Soames, C. \& Stevenson, A. (eds.), 2008, Concise Oxford English Dictionary, University Press, Oxford, pp. 455.

Thrupp, M. \& Willmott, R., 2003, Education management in managerialist times: Beyond the textual apologists, Open University Press, Maidenhead.

Tikly, L., 2003, 'Governmentality and the study of education policy in South Africa', Journal of Education Policy 18(2), 161-174. http://dx.doi. Africa', Journal of Education Polit
org/10.1080/0268093022000043074

Tobing, E., 2013, 'Promoting religious tolerance: What does religious tolerance mean?', in The Prospect, viewed 14 January 2013, from http://www. theindonesianinstitute.org/pers020706.htm

Torres, C.A., 2002, 'The state, privatisation and educational policy: A critique of neo liberalism in Latin America and some ethical and political implications', Comparative Education 38(4), 365-385. http://dx.doi.org/10.1080/0305006022000030766

Van der Walt, J.L. \& Fowler, S., 2006, 'Constructivist teaching-learning theory: A stewardship approach', in B. de Muynck \& J.L. van der Walt (eds.), The call to know the world: A view on constructivism and education, pp. 13-50, Buijten \& Schipperhein Motief, Amsterdam.

Van der Walt, J.L. \& Potgieter, F.J., 2012, 'Research method in education: The frame by which the picture hangs', International Journal of Multiple Research Approaches 6(3), 220-232. http://dx.doi.org/10.5172/mra.2012.6.3.220

Van der Walt, J.L., Potgieter, F.J. \& Wolhuter, C.C., 2010, 'The road to religious tolerance in education in South Africa (and elsewhere): A possible "Martian Perspective"', Religion, State and Society 38(1), 29-52. http://dx.doi. org/10.1080/09637490903500507

Vermeer, P. \& Van der Ven, J.A., 2004, 'Looking at the relationship between religions: An empirical study among secondary school students', Journal of Empirical Theology 17(1), 36-59. http://dx.doi.org/10.1163/1570925041208899

Visanmiu, T., 2012, 'What is the meaning of tolerance in the modern qorld?', in Theodorvisanmiu, viewed 26 April 2012, from http://theodorvisanmiu.wordpress. com/2012/04/26/what-is-the-meaning-of-tolerance-in-the-modern-world

Visker, R., 1996, 'Mensen gedragen zich als eigenaars van verschil: Report by Mannus van der Laan', DELTA: Weekblad van de Technische Universiteit Delft, 28, viewed 01 August 2008, from http://www.delta.tudelft.nl/nl/archief/artikel/mensengedragen-zich-als-eigenaars-van-verschil/12002

Visker, R., 1997, 'The core of my opposition to Levinas', Ethical Perspectives 4(2), 154 170. http://dx.doi.org/10.2143/EP.4.3.562999

Visker, R., 2004, The inhuman condition: Looking for difference after Levinas and Heidegger, Kluwer Academic Publishers, Dordrecht/Boston, MA/London.

Visker, R., 2005, 'Two readings of Heidegger's Der Satz vom Grund', public lecture, University of Pretoria, Pretoria, 25 June.

Walzer, M., 1997, On toleration, Yale University Press, New Haven, CT.

Webster, E. \& Mosoetsa, S., 2002, 'At the chalk face: Managerialism and the changing academic workplace 1995-2001', Transformation 48, 59-82.

Wolhuter, C.C., Van der Walt, J.L. \& Potgieter, F.J., 2014, 'Modelle van inter-religieuse toleransie in die onderwys van die een-en-twintigste eeu', In die Skriflig/In Luce Verbi, submitted.

Wright, N., 2001, 'Leadership, "bastard leadership" and managerialism. Confronting twin paradoxes in the Blair education project', Educational Management and Administration 29(3), 275-290. http://dx.doi.org/10.1177/0263211X010293003

Wright, R., 2009, The evolution of God, Little, Brown and Company, New York, NY.

Zagorin, P., 2003, How the idea of religious toleration came to the West, Princeton University Press, Princeton, NJ.

Zipin, L. \& Brennan, M., 2003, 'The suppression of ethical dispositions through managerial governmentality: A habitus crisis in Australian higher education' International Journal of Leadership in Education 6(4), 351-370. http://dx.doi. org/10.1080/1360312032000150742 